\title{
The Translator's Subjectivity in The Golden Cangue from the Perspective of Feminism
}

\author{
Chunrong $\mathrm{Wu}^{1, *} \&$ Fei $\operatorname{Tan}^{2}$ \\ ${ }^{1}$ School of Foreign Languages, Sichuan University of Science \& Engineering, China \\ ${ }^{2}$ School of Automation and Information Engineering, Sichuan University of Science \& Engineering, China \\ ${ }^{*}$ Correspondence author: School of Automation and Information Engineering, Sichuan University of Science \& \\ Engineering, Xueyuan Road No. 180, Zigong City 643000, Sichuan Province, China. Tel: 86-139-9006-0278. E-mail: \\ 363493649@qq.com
}

Received: July 31, 2017

Accepted: August 30, 2017 Online Published: Sptember 17, 2017

doi:10.5430/wjel.v7n3p24

URL: https://doi.org/10.5430/wjel.v7n3p24

\begin{abstract}
The feminist translation theory holds that translators who bear social, cultural, and gender features are bound to put some special brands into their works in the process of translation. The Golden Cangue, one feminism novel, is self-translated by Eileen Chang, a famous Chinese writer, and released overseas. The paper starts with a brief introduction to some relevant theories about feminism translation and the subjectivity of translators; next, a profound study on the English version of The Golden Cangue is carried out through the analysis of the strategies used in some sentences reflecting the subjectivity of translators; finally, the paper provides some introspections and weakness about the subjectivity of translators.
\end{abstract}

Keywords: feminist translation; subjectivity; The Golden Cangue; translation strategy

\section{Introduction}

With the emergence of feminism in the middle of the $20^{\text {th }}$ century, the combination of translation and culture brought the translators' identity into the sphere of cultural identity. As a result, the feminism translation was born. Meanwhile, a fact which has long been ignored was put forward when the subjectivity of translators was discussed. Namely, gender was never paid due attention and the sex of a translator.

We probe into the subjectivity of translators from the perspective of feminism based on The Golden Cangue self-translated by Eileen Chang in order to cast light on the translators' impact on translation especially some unique translation strategies and skills which can be applied to other translations and promote people's understanding towards translation.

\section{The Origin of Feminist Translation Theory}

Originated from the Liberal Feminism of the 18th century, the feminist movement advocates gender equality and women' liberation movements to acknowledge women' claim for rights equal to those possessed by men. Being excluded from the privileged society, women usually regarded translation as an accessible way to express themselves in public. Since the middle ages, translation has been a significant channel for European women to enter the literature realm. It was until the $20^{\text {th }}$ century that translation was still considered as a writing training for women. "From the 1980s up to now, feminism began to intersect with postmodernism, deconstruct the patriarchal language and binary oppositions and decentralize the power and knowledge dominated by male" (Wang Jingjin, 2010). Feminists put great premium on language in constructing gender differences. "Attention was drawn to the fact that language is not only a tool for communication but also a manipulative tool" (Flotow, 2004).

As an important voice for translation studies in "cultural turn", feminists have their own understandings towards translation. For a long time, women have been considered inferior to men and were forbidden to publish literary works. And translation was thought to be secondary to the original at that time, so translation was the only way to 
utter women' voices. The marginality of women in society was linked with that of translation in the literary hierarchy. "Terms such as 'les belles infideles' express the disparagement of both women and translation" (Andone, 2002:137). "Patriarchy and logocentrism have much in common and they meet in translation. The original is the natural, the truth and paternal authority, whereas the translation, the woman, is secondary, an imitation" (ibid, 138). Therefore, "the task of feminist translation theory is to identify and discuss the concepts which place both women and translators at the bottom of the system" (ibid, 137).

\section{The Characteristics of the Subjectivity of Female Translators}

While the concept of gender becomes the focus of western society, people find that the so-called sex differences are not inherent but forged by society and its culture. In a society dominated by male, female has to accept her inferiority to male. At the same time, men are entitled to control both society and language. However, both women and their languages are marginalized by society and culture, which bears resemblance with translators who are also in a low status. Female translators usually imbed their ideology into translation. It reveals that subjectivity as a medium exists between two cultures and languages, absolutely original connotations are reconstructed and diversification matters a lot. They hold that they should interfere with the text translation so as to accord with feminism ideology. Besides, the notion that translation is the cooperation between translators and authors expresses feminist' position and improves translators' self-awareness. "Translators not only can impart life to the original works but also can determine what and how to make them become part of the target language" (Lefevere, 1992). Female translators maintain that a successful translation is able to help the original works surpass the limit of both time and space and guarantee its cultural connotations in different times.

\section{The Analysis on the Subjectivity of Eileen Chang Reflected in The Golden Cangue}

Deep feminist awareness abounds in The Golden Cangue self-translated by Eileen Chang. In the course of literary creation and translation, she tries to emphasize the subjectivity of translators, which puts premium on the dignity and equality of female. It aims to display the unique translation style as well as strategies of women to eliminate the discrimination against female in traditional translation research. Therefore, The Golden Cangue is fraught with the ideas of the subjectivity of feminist translators.

\subsection{Individualized Translation}

Individualization of translation language plays an important role in literature works since it not only conveys the messages of works to readers but also reflects the language style of translators. Well-designed dialogues can embody the distinctive personalities of different characters. The feminization of speeches is characterized as short sentences and varied vocabularies which is true of the translation versions of Eileen Chang. By selecting proper words and using the strategy of supplementing, female translators attempt to show their subjectivity.

Eg.1 “代珍站起身来道: 我去看看。别焦这位小姐好性儿, 逼急了她, 也不是好惹的” (张爱玲, 2009)。

"Tai-chen stood up, 'I will go and see. This young lady may be good-temper, but she can fight back if cornered" " (Eileen Chang, 1971).

In this sentence, the translator uses “fight back" to explain the meaning of derogatory word of “不是好惹的” in Chinese. It manifests that the lady in this novel is hard to cope with. In such way of individualized translation, a strong desire for female independence is reflected that women would take an initiative to fight back rather than resign themselves to obstacles set purposely by others. Therefore, the subjectivity of female is highlighted,.

\section{Eg.2 “老太太上了年纪，有点聋，喉咙特别高些，有意无意间不免有些话吹到阳台上的人的耳朵}

里” (张爱玲, 2009)。

"Old mistress, being of advanced age, was a little deaf, so her voice was especially loud. Intentionally or not, the people on the veranda heard much of the talk"(Eileen Chang, 1971).

In this paragraph, the translator substitutes the “老太太” with "Old Mistress" which improves the authority of this character in translation version. Besides, it also demonstrates that the “老太太” in the original is not only purely an old lady but also the most respected and prestigious person in the whole family. “上了年纪” is replaced by "advanced age", an euphemism style, which displays the special high status of this character. The translator's settlement toward the two phrases which meets the original context and reflects innovation carries obviously the 
subjectivity of feminist translators.

\subsection{Equalized Translation}

In the process of translation, Eileen Chang reinterprets the image and encounter of females as they were in the original through careful wording and sentence-making. It intends to enable both translators and readers to share the same feelings with the authors. Under such circumstance, being both the author and translator of The Golden Cangue, Eileen Chang has an identical experience of literary creation with another language; in other words, it is another reflection of the subjectivity of translators.

Eg.1 “七巧止不住一阵心酸，倚着箱笼，把脸偎在那沙蓝棉套子上，纷纷落下泪来”（张爱玲， 2009)。

"Chi-Chiao felt a wave of acid pain rising in he heart and could not restrain a shower of tears as she leaned against the trunks, her face pressed against their padded covers of sandy blue cloth"(Eileen Chang, 1971).

In this paragraph, the translator adopts equalized translation. Instead of making any supplement or deduction of the original, she reproduces the ambivalent emotion embraced by Chi-Chiao at the sight of her relatives. For instance, by translating “一阵心酸” into “a wave of acid pain rising in her heart” and “纷纷落下泪来” into “ a shower of tears", readers can feel the same scene with the original. In line with the narrative style and pace of the original one, the translation version is imparted with inherent sentence patterns, vivid metaphors as well as striking images, making people lost in deep thought. Generally speaking, vocabularies and speeches with Chinese characteristics in the original are settled in a special way in order to retain the language style exclusive to China, which reflects the subjectivity of feminist translators.

Eg.2 “窄窄的袖口里垂下一条雪青洋约手帕，身上穿着银红衫子，葱白线香滚，雪青扇蓝如意小 腿裤子, 瘦骨脸儿, 朱口细牙, 三角眼, 小山眉……”(张爱玲, 2009)。

"On her thin face were a vermilion mouth, triangular eyes, and eyebrows curved like little hills. She wore a pale pink blouse over narrow mauve trousers with a flickering blue scroll design and greenish white incense-stick blinding. A lavender silk crepe handkerchief was half tucked around the wrist in one narrow blouse sleeve..." (Eileen Chang, 1971).

In this excerpt, the original long sentence is divided into three sentences by adjusting the sentence order. Opposite to the original, the translation version begins with the description of the facial features of Chi-Chiao and then proceeds with her dressings, which is characteristic of the writing and thinking style of westerners. However, some vocabularies with Chinese characteristics are translated as they are and the original language style and intentions are retained at their most. By translating these words equally rather than making any supplement or deduction, a vivid and exact image identical to the original can be plainly presented in readers' mind. Unlike other translation strategies, such settlement fully reflects the subjectivity of feminist translators.

\subsection{Intensified Translation}

In order to make readers in English-speaking countries fully understand the miserable fates of Chinese women fettered by social systems and customs, Eileen Chang adopts intensified translation by reinforcing some connotations of the original with a variety of methods so as to highlight and intensify narrative style of women.

Eg.1 “她的背影一挫一挫, 俯伏了下去, 她不像在哭, 简直像在翻肠倒胃地呕吐” (张爱玲, 2009)。

"Her back convulsed as it sank lower and lower. She seemed to be not so much weeping as vomiting, churning and pumping out her bowels" (Eileen Chang, 1971).

In this paragraph, intensified translation is frequently applied. For example, the original “一挫一挫” is directly translated into a single word of "convulsed" and “俯伏” into "sank lower and lower". These brief but vivid expressions are typical of western readers; the sentence pattern of "not so much ....as ..." is smartly used in the second sentence and the original “翻肠倒胃” is greatly intensified by three apposite verbs of "vomiting, churning and pumping out". The reason why Eileen Chang adopts intensified translation is that she wants to meet the needs of western readers and manifest her attitude toward the miserable fate encountered by Chinese women. Thus, the subjectivity of translators is demonstrated naturally.

Eg.2 “季泽是个结实的小伙子, 偏于胖的一方面, 脑后拖着一根三脱油松大辫, 生的天圆地方, 鲜红的腮规.......” (张爱玲, 2009)。

"A robust youth, tending towards plumpness, Chiang Chi-tse sported down his neck a big shiny three-stand pigtail loosely plaited. He has the classic domes forehead and squarish lower face, chubby 
bright red checks..." (Eileen Chang, 1971).

In this paragraph, intensified translation is applied in two places. Based on the differences between two cultures, the translator employs various translation theories to get readers to feel the same situation in the translation version and show her subjectivity. Firstly, the translator modifies the sentence pattern by putting the subject of "Chiang Chi-tse" in the beginning of the second sentence instead of the first one; next, the “脑后拖着一根三脱油大辫” is translated into " sported down his neck a big shiny three-stand pigtail loosely plaited" in which “脑后” is replaced by "neck"; what's more, “生的天圆地方” in the original, typical of Chinese expressions, is freely translated into " the classic domes forehead and squarish lower face". In such way, the translation is infused with new bloods and easier for readers in different cultures to understand.

\subsection{Creative Translation}

Due to differences in cultures and languages, it is inevitable for Eileen Chang to apply creative translation skills and strategies into the translation versions. She must give a full play to her subjectivity by coping with some original words innovatively, which is consistent with the feminist translation theories of another type of being loyal to the original.

\section{Eg.1 “季泽正在弄堂里往外走, 长衫搭在肩上, 晴天的风像一群白鸽钻进他的纺绸补子里, 哪儿} 都钻到了，飘飘拍着翅子” (张爱玲, 2009)。

"Chi-tse was just going out the alley, his gown slung over his arm. Like a flock of white pigeons, the wind on that sunny day fluttered inside his white silk blouse and trousers. It penetrated everywhere, flapping its wings" (Eileen Chang, 1971).

In the above paragraph, Eileen Chang translates “纺绸裤褂” into “white silk blouse and trousers" in which the word of "white" is added in order to correspond to the prior " white pigeons". Later, the verb of “钻” is substituted by "flutter" and "penetrate" respectively. Innovative wording and translation in such way makes the translation version more exact and vivid from which readers will make it easier to learn about the implications and the consciousness of feminist translators.

Eg.2 “兰仙平生最大的憾事便是出阁的日子正赶上非常时期, 潦草成了家, 诸事都欠齐全, 因此 一听见这不入耳的话, 她那小长桂子脸便往下一沉” (张爱玲, 2009)。

"Lan-hsien's greatest regret was that her wedding had happened in a period of national emergency and lacked pomp and style. As soon as she heard these jarring words, her narrow little face fell to its full length like a scroll'(Eileen Chang, 1971).

In the above excerpt, Eileen Chang, considering the general background at her ages, interprets the “非常时期” as "national emergency", which is creative and consistent with the original tone; “不入耳的话” is translated into " jarring words" in which " jarring", originally refereeing to harsh sound, is imparted with abstract implication; the word of "scroll" is supplemented to the last sentence to visualize the long face of Lan-hsien. By translating those words in a creative way rather than literal translation, not only the creation background can be easily seen, but also the vivid image of a character can be more visualized. Such treatment indicates that the translator tries to choose creative words in a positive way to express the subjectivity of feminist translators

\subsection{Ironic Translation}

Ironic language, a commonly used one in the original works of The Golden Cangue, makes it plain and easy for readers to understand; besides, it infuses a sense of humor as well as irony into the novel. In order to keep the sarcastic tone of the original, Eileen Chang, being both the author and translator, attaches great importance to the reappearance of ironic and humorous language in the translation versions. Therefore, the ironic translation strategy is applied accordingly, an indication of the subjectivity of feminist translators.

Eg.1 “麻油店的活招牌, 站惯了柜台, 见多识广的, 我们拿什么去和人家比”（张爱玲, 2009）？

"Why, she was the big attraction at the sesame oil shop, standing at the counter, and dealing with all kinds of customers. What have we got to compare with her" (Eileen Chang, 1971)?

By replacing “见多识广” with “dealing with all kinds of customers”, Eileen Chang plans to satirize the unbalanced minds of those servants. Adept at social intercourse and known as an able woman, Chi-Chiao is unavoidably envied by other women who are inferior to her on serving customers and doing business. These servants can do nothing but give some sarcastic remarks to release their anger and contempt Chi-Chiao, which reveals their jealous nature. The ironic settlement of these words manifests the humble family background of the heroine and the strong jealousy 
shared by these servants.

Eg.2 “她突然坐起身来，低声道：“男人……碰都碰不得！谁不想你的钱？你娘这几个钱不是容易 得来的，也不是容易守得住……我可不能眼睁睁看着你们上人的当”（张爱玲，2009）。

“She suddenly sat up to whisper, 'Men...leave them alone! Who's not after your money? Your mother's bit of money didn't come easy nor is it easy to keep...I can't look on and see you get cheated. I am telling you to be more on guard from now on, you hear'" (Eileen Chang, 1971).

This paragraph is literally translated, which is full of irony. While destroying herself, Chi-Chiao attempts to ruin other women around her. She won't allow her children to gain love or happiness which she doesn't get. Not only their lust for emotion is eradicated but also their future happiness is destroyed. Her thirteen-year-old daughter, Chang An, who is warned to stay away from men, eventually is reduced into a resentful woman hostile to men from a girl longing to be loved, living in fear and fetter throughout her life. Just as Eileen Chang described, Chi-Chiao is something of the cautiousness and resourcefulness like a lunatic man. By imbedding strong irony into these sentences, readers are able to easily perceive the extremely twisted psychology and mind of the heroine; the negative image of this character is reinforced naturally; and the social practice that some materialists suffering from feudal thoughts prioritize money over other things is repudiated severely at the same time. Such unique and sarcastic translation strategy, meanwhile, expresses the subjectivity of feminist translators.

\section{Conclusion}

Recently, in the course of studying issues about the subjectivity of translators, great importance has been attached to the identity of translators. However, according to feminist translation theories, gender, an imperative perspective, hasn't been given due consideration. So it is of practical significance to explore the subjectivity of translators from the perspective of feminists. Besides, it promotes the development of translation research and the deep study on the identity of translators. Based on The Golden Cangue self-translated by Eileen Chang, this paper carries out a tentative analysis on the sentences or paragraphs reflecting the subjectivity of feminist translators.

\section{References}

Andone, Oana -Helena. (2002). “Gender Issues in Translation” Perspectives: Studies in Translation. Beijing: Tsinghua University Press.

Chang Eileen. (1971). Golden Cangue in Twentieth-century Chinese stories. New York: Columbia University Press.

Flotow, Louise von. (2004). Translation and Gender. Shanghai: Shanghai Foreign Language Education Press.

Lefevere, Andre. (1992). Translation, Reviewing \& the Manipulation of Literary Fame. London \& New York: Routledge.

Wang Jinjing. (2010). A Brief Introduction to Feminist Translation Theory in the West. Read and Write Periodical, 6, 24.

Change Eileen. (2009). The Golden Cange. Bejing: Beijing Publishing Group. 